\title{
Alliance-Based Global Strategy
}

\subsection{Introduction}

When creating new operations overseas, companies must fulfill various requirements, such as providing benefits for local employees, finding sources for materials and parts, creating logistics infrastructure including new distribution channels, and gaining regulatory approval for the operations. Instead of doing these tasks independently, it is more practical for companies to cooperate with local businesses. In addition, companies can reduce their overseas investment risk through joint ventures (i.e., joint investment companies) with local entities instead of creating wholly owned local subsidiaries. Without cooperation with a local company, it becomes difficult to smoothly launch new business operations in emerging nations such as China and India, which have business environments that are very different from those of advanced countries. As stated in Chap. 4, these emerging countries do not possess adequate market mechanisms or economic legislations such as corporate law, making business transactions unpredictable. Alliances with local companies are effective in filling such institutional voids (Khanna and Palpu 2010). However, expanding operations via joint ventures with local companies does have the disadvantage of diminished autonomy because of the intervention of local firm's management. Even when companies decide that increasing headquarters' control in a company-wide global strategy is an appropriate course of action, it is possible that the strategy might not come to fruition because of opposition by joint venture partners. In this chapter, we first analyze the option of a joint venture with a local partner when expanding globally, and then present a formal discussion on strategic alliances. A joint venture is a form of alliance; however, companies can also form contractual alliances, such as licensing agreements and joint operating agreements. In addition, many relationships with strategic alliance partners extend to the long term, and alliance management skills after establishing a joint venture or entering into an agreement have a tremendous impact on performance. In this chapter, we 
discuss the following three necessary management phases: (1) the alliance project development phase, (2) the alliance structure design phase, and (3) the alliance execution phase.

Finally, we examine local government partnerships. As discussed in Chap. 5, overseas infrastructure development operations often take the form of PublicPrivate Partnerships (PPPs), in which a government and a private industry jointly manage operations that have been the domain of local governments in the past. In emerging countries, many Western companies aggressively participate in infrastructure operations such as water distribution, railways, and roadways. Moreover, there has been a lag in Japanese companies' participation; however, the Japanese government has recently taken measures to encourage "infrastructure exports." Currently, these infrastructure operations in emerging markets have gained momentum from both public and private sectors. As an example of an alliance with government or public institutions, we discuss infrastructure operations and deepen our understanding of management issues specific to PPPs which are different from alliances between private corporations.

\subsection{Wholly Owned Subsidiary or Joint Venture with Local Companies}

In this chapter, we discuss the options of establishing a wholly owned local subsidiary and creating a joint venture with a local company. In joint ventures, the influence of the local partner on management varies in terms of the share of investment. As a general rule, if the parent company is the majority investor (i.e., $51 \%$ or more of the total investment), it can control the operations for those matters that can be decided by the majority vote. However, critical management issues sometimes require a two-third vote or an agreement of a super majority, during which the company cannot ignore the influence of a minority partner on the management.

Furthermore, in emerging countries, companies must exercise caution because government regulations often cap the level of investment by foreign firms. For example, in China's automotive industry, foreign firms are limited to hold up to a maximum stake of $50 \%$ in a joint venture. Toyota and Volkswagen have entered the Chinese market through joint ventures with local companies: Toyota partnered with the FAW Group and the Guangzhou Automobile Group Co., and Volkswagen partnered with the FAW Group and the Shanghai Automotive Industry Corp. In emerging countries, private companies are not adequately mature, and joint venture partners are often government owned. Toyota's and Volkswagen's joint venture partners are government owned. Therefore, in such cases, companies negotiate joint ventures with governments, making it difficult for companies entering the market to firmly negotiate conditions. In this book, we discuss the cases of Hitachi Construction Machinery (Chap. 8) and Shiseido (Chap. 10), and their entry into the Chinese market, as well as Suzuki Motor Corporation's (Chap. 14) entry into the Indian market. In all of these cases, the governments in the host countries requested the companies to enter their markets as joint venture partners. Investment regulations for foreign 
firms have recently begun to relax in emerging countries; however, even in cases where companies enter a market via a wholly owned local subsidiary, it is best to maintain good relations with the governments in the target countries.

We now summarize the strengths and weaknesses of wholly owned subsidiaries and joint ventures with the assumption that companies entering a market can freely choose either form. One advantage of a wholly owned subsidiary is the freedom of management toward the local entity. In particular, when entering via a globally integrated management as per I-R grid (i.e., "I"-type management) covered in Chap. 2, a company must ensure that the local entity is given a certain degree of discretion in management. On the other hand, when entering via a joint venture, companies can mitigate their market entry risks. Suzuki Motor Corporation entered India in 1982 via a joint venture with Maruti Udyog with a total investment of $26 \%$ in the venture. This was the first case of a foreign company entering India's automotive industry, thereby placing Suzuki in a high risk situation. This is why Suzuki decided to limit their level of investment. The Indian government, in fact, offered Suzuki to make a $40 \%$ investment; however, Suzuki was adamant about maintaining the lowest possible share, sufficient for the company to exercise veto rights for important management-related decisions (where a three-quarters vote was required).

In addition, when companies expand overseas via joint ventures, their likelihood of having a smooth local launch increases. In the case of production facilities, such as factories, companies do not have much to gain technically from companies in emerging countries, but local sales necessitate the creation of customer relationships and retail and distribution channels, which can be difficult without support from local partners. Partnering with companies with already existing local channels enables the rapid launch of operations. Furthermore, when government-owned companies are joint venture partners, companies can make allies of the government, which is necessary in running operations in emerging countries. This model has many advantages for local operations.

When deciding between a wholly owned subsidiary and a joint venture, companies must weigh the advantages of "freedom in managing the local entity" versus "local risk factors." In other words, companies must balance between the expected profit from the management resources of their joint venture partners (e.g., distribution channels or local government relationships) and the costs related to those resources. For example, companies may discover that the retail stores and other parts of the distribution channel held by the joint venture partner are inefficient, and the benefits of using existing channels are low. In that case, local entities must create new distribution channels and strengthen their sales capability, despite the possibility that the company cannot establish new sales routes as was hoped because of opposition from existing retail stores. On the other hand, if a joint venture partner has a powerful distribution channel, they are likely to demand more in return. How should companies respond to joint venture partners that predicate cooperation on receiving high-level product technology? Although this process is rather difficult to achieve, entering companies must clarify the joint venture partner's management resources and the conditions of forming a joint venture, while both parties attempt to disclose information to each another during negotiations. This is particularly true 
for companies that speak different languages with different business environments. Accordingly, entering into a joint venture with a local company can be an effective means of reducing investment risks in the target country when a company signs a joint venture agreement. However, companies must be careful of the increased risk as compared with entering a new market as a wholly owned subsidiary.

The company's ability to manage such an increased risk is significantly dependent on its global business experience. The business environment, government relations, and the types of risks that are manifest are different in target countries. Therefore, management style undertaken by the company in China should differ from the one undertaken in India. Risk analysis in each country should not only utilize various information sources and the advice of consulting firms, but also create a knowledge base of experiences of companies to create an infrastructure that makes the most of new project formulation.

In Chap. 2, we stated that Japanese companies often use a "globally integrated" form of organization, compared with their European and US counterparts. However, as a result, Japanese companies often enter markets as wholly owned subsidiaries rather than create joint ventures. For example, according to the results of a 2005 survey on medium- to large-sized foreign manufacturing firms in China, the percentage of foreign subsidiaries was approximately $60 \%$ among Japanese companies, and only approximately $40 \%$ among Western companies (Motohashi 2011). Japanese companies lack the ex post risk management ability required for joint ventures, resulting in a higher percentage of wholly owned subsidiaries and increasing the likelihood of companies not enjoying the benefits offered by joint ventures. Typical Japanese companies striving for a transnational form of management organization must strengthen their local orientation, for which reinforcing the management capability of joint ventures with local companies becomes critical.

\subsection{Alliance Forms and Management Methods}

For global businesses leveraging joint ventures, the economic value derived from the joint venture is an important consideration. Joint ventures require win-win situations that are beneficial to both the company and its alliance partners. Alliances include capital transactions with a partner company, as in the case of joint ventures, as well as agreement-based relationships, such as licensing or joint operating agreements, with local companies. In a discussion of whether a company should have a joint venture or a wholly owned subsidiary as per the preceding paragraphs, a comparison is made for capital transaction between the case of an alliance with another partner and that of external transactions where the acquiring company has an initiative. When creating a local entity that is a wholly owned subsidiary, they can do so via green-field investment or acquisition of a local entity. The latter is done as an external capital transaction and differs from a joint venture such that the transaction focuses on the acquiring company (Fig. 7.1).

Contract-based transactions sometimes require alliances with other companies and involve subcontracting or outsourcing while maintaining company focus. 


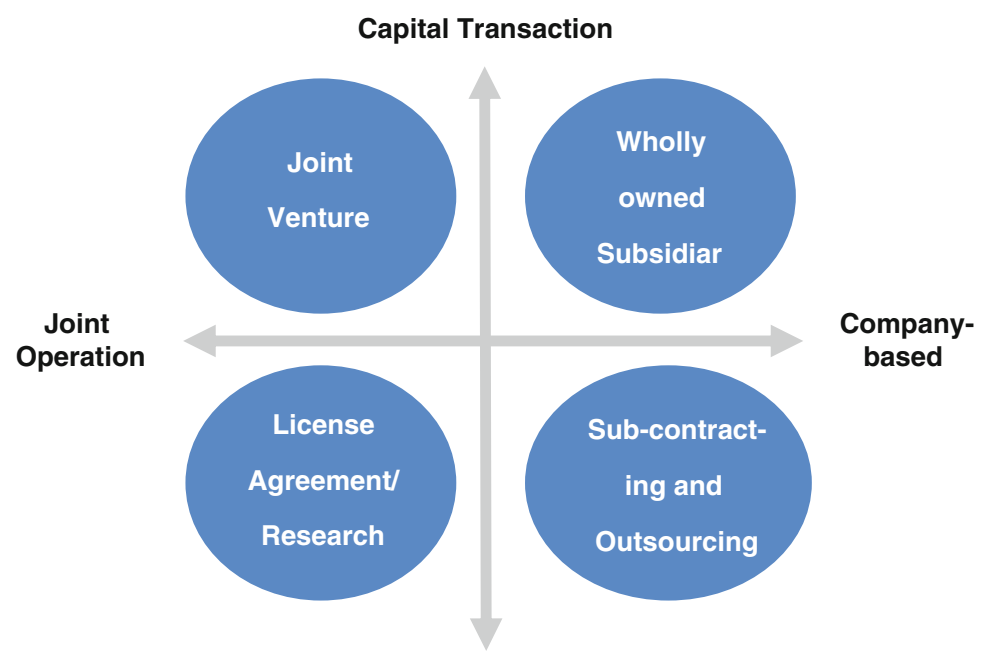

\section{Contract Base}

Fig. 7.1 Comparison of business transaction types

Regarding the differences between capital transactions (joint ventures) and contract-based licensing and joint operating agreements, as was explained in the preceding paragraphs, the joint infusion of capital from a foreign and a local company to create an entirely new local entity is characteristic of joint ventures. On the other hand, a license agreement does not involve new entity creation, but is rather a way to launch a new business in partnership with a local company on contract basis. For example, a foreign company may provide the technology with which a local company manufactures products on the basis of a technology introduction agreement, and sells them to the local market. In doing so, as defined by the license agreement, the local company pays a certain percentage of revenue to the foreign company as a license fee. Joint operations, such as joint development or joint production, are managed by contract that decides capital splits and the attribution of results to achieve a specific operational goal held by multiple companies. We divide the management used to promote these alliances into three phases: (1) the alliance formulation phase, (2) the alliance structure design phase, and (3) the alliance execution phase (based on Kale and Singh (2009)).

The alliance formulation phase begins with a search for a joint operation partner. For example, let us consider a Japanese consumer electronics manufacturer that is intent on entering the Chinese market and is in search of an alliance partner. It is a fact that operations in China will reduce the cost of production; however, for this they will require the creation of distribution channels. The manufacturer realizes that a local partner is necessary as this will not be feasible with company resources alone. What are the requirements of an optimal partner? Having complementary business resources are certainly important in forming an alliance. The Japanese consumer electronics manufacturer possesses production technology with superior 
low-energy requirement and functionality. However, from a price perspective, selling these products will be difficult in China, therefore requiring the manufacturer to reduce production costs and trim functionality to localize the product. Furthermore, the company needs to establish distribution channels in the Chinese market. Integrating all of these requirements, we conclude that the optimal partner for this company will be a large consumer electronics manufacturer with a high market share and a certain amount of technical capability in China, thus creating a win-win situation for both parties. Assume that the Chinese consumer electronics manufacturer asks for technology that it does not possess currently, such as energy-saving technology, in exchange for its distribution channels. The Japanese manufacturer must carefully analyze and respond to these demands with caution, for the risk of losing the deal because of inadequate incentives to form an alliance with the foreign company.

Selecting an alliance partner in this manner requires identifying business resources that are complementary to both parties and finding a form of partnership that is beneficial to both. However, it is often the case that neither of the two parties fully understands the benefits of the alliance until it is operational. Thus, in addition to the complementarity of the business resources, consistency of management styles and a mutual commitment to the alliance is also important (Beamish 1987). For example, in terms of management styles, companies may choose to focus on shortterm profits or build long-term businesses, or several other areas, such as respond to environmental issues. When these fundamental management philosophies are aligned, companies will most likely not hold adversarial opinions in their partnership. In terms of commitment, it is ideal for both parties' managements to communicate regarding the alliance and work constructively toward the goals of the alliance when any differences in opinion arise.

Deal formulation takes place at the alliance structure design phase: should a company create a capital partnership or an agreement-based partnership, and what specifically should the contents of the agreement look like? Large capital investments by both parties of the joint venture require a strong commitment from both sides to jointly manage the business; this form of alliance has the benefit of engendering an awareness of both parties being "in the same boat" (Hennart 1988). In addition, the rules for distributing results generated by the alliance are made clear by the levels of investment made by each party. However, establishing the new joint venture company entails a large sunk cost, making it difficult to rectify major course corrections in managing operations and compromising flexibility. For example, after the initiation of joint venture operations, if the economic environment changes or results do not meet expectations, reaching an agreement to dissolve the joint venture can be difficult. Even for a single company, the decision to exit an unprofitable business is difficult and takes time. In the case of a joint venture, the decision must be made simultaneously by both companies.

On the other hand, efforts to create agreement-based alliances, such as those based on license agreements or joint operating agreements, enable a more flexible 
response to agreement changes or perhaps even dissolution of the joint operations. However, this flexibility comes with limitations: neither party commits to the alliance. For alliances, the fact that both parties work together to create new value is critical, and often, alliances do not work if neither party is committed. In other words, agreement-based alliances are effective when both parties have clear delineations of responsibility and results are expected in a relatively short timeframe. On the other hand, capital-based alliances with clear commitment from both parties are required for building cooperative relationships over a long timeframe and across broad areas.

Finally, we discuss the alliance execution phase, a period when the joint venture is established or a license agreement has been entered into, and the alliance shifts into the execution stage. Returning to the example of a Japanese consumer electronics manufacturer entering the Chinese market, it is expected that the local company alliance will extend into the long term. On the other hand, the Chinese economic environment is rapidly changing, and urbanization, along with lifestyle improvement among Chinese citizens, is resulting in a change in demand for consumer electronics products. Accordingly, the process of going ahead with a partnership may be accompanied by unforeseen circumstances after the alliance agreement is signed, and appropriate corrections will need to be made through mutual discussions to analyze the direction of the alliance. Trust between the parties is important in this case. Repeating the process of negotiation, mutual understanding, commitment to compromise, and the execution of compromise consistently are necessary to build this trust (Ring and Van de Ven 1994). Alliance partners share highly confidential information through this process, therefore, reducing the asymmetric nature of information among the parties. This results in clearer compromises on both parties and lesser indulgence in opportunistic behavior, which can be detrimental to the other party. Building trust among alliance partners is the most effective means to reduce the risk of entering into an agreement-one of the demerits of joint ventures.

So far we have discussed the management of different types of alliances; we conclude with the overall countermeasures that a company may undertake. As previously stated, alliance management differs by country, region, industry, and type of operation. Because alliances presuppose multiple parties, building effective relationships greatly influences partnership results. Thus, using company experiences and organizational efforts in a potential alliance is critical toward the overall improvement of the alliance. Building alliance knowhow organizationally requires a department specialized in alliance management (Anand and Khanna 2000). Western companies, such as Hewlett-Packard, Eli Lilly, and Philips, have established such departments, thereby increasing the success rate of their alliances (Kale and Singh 2009). In Japan, efforts are being made to create such departments that focus on alliance management, particularly among pharmaceutical companies; however, Japanese companies still lag behind Western companies. Creating a dedicated alliance function at the firm is an effective means to accumulate knowhow from existing partnerships and to use this knowhow in new potential alliances. 


\subsection{Governments as Alliance Partners in PPP Infrastructure Businesses}

So far we have examined alliances between private corporations. This section analyzes the issue of partnering with local governments as a means of expanding globally. Using the example of PPPs, which mainly deal in infrastructure-related projects, such as roadways, railways, and waterworks, we summarize the salient features of partnering with governments and the management involved in such partnerships.

In Chap. 5, we discussed the systems integration business in the context of infrastructure exports. For example, providing rail transportation services for people and freight requires the knowledge of signal systems, railcar management, and other operational factors, in addition to hardware infrastructure such as rolling stocks, railways, and stations. This, in turn, requires the creation of an overall consistent system that combines all of these elements, which are fine-tuned to function with all other parts. In addition, we discussed the necessity of systems integration, focusing on technical peculiarities to build such a large-scale system. In this chapter, we focus our discussion on the organizational aspects of managing actual operations, in particular, the partnering of public and private sectors to facilitate a successful venture.

Figure 7.2 presents a typical PPP business organizational structure. First, the government or public institution (in the case of railways, a business management agency such as a nationalized rail company) is the primary entity behind the public works service. The government (or public institution) enters into a PPP agreement with a special purpose company (SPC) established specifically for the purpose of maintaining the infrastructure-here both public and private entities manage the

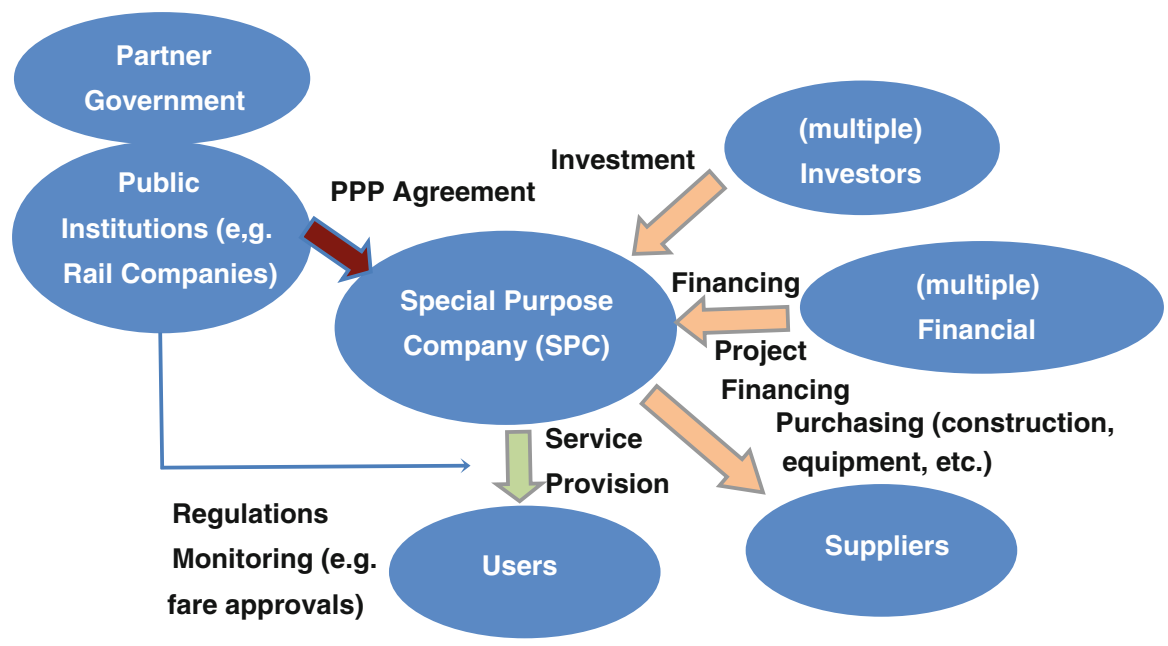

Fig. 7.2 Structure of PPP (Public Private Partnership) 
business. One form of PPP agreement often used is the build, operate, and transfer (BOT) method. In such a method, the government subcontracts the building and operation of infrastructure, after which the private company transfers ownership of the infrastructure back to the government once the business is complete, over an extended period of 30-40 years. The business is operated according to the agreement entered into with the government, thus providing rail or other public services to ordinary users. The company is subject to safety regulations, fee approvals, and other forms of oversight. Many SPCs involve joint ventures with multiple companies, in which an investment company provides the capital and the banks provides the project finance. In addition, the SPC orders construction services and equipment from construction companies, equipment manufacturers, and other suppliers to create the infrastructure. On the project's entry to the business operation phase, the SPC subcontracts business management to specialists. Infrastructure companies such as Alstom and Bombardier in the railway business, and Veolia and Suez in the waterworks business are suppliers to specialty firms such as equipment manufacturers and business operation specialists; these infrastructure companies are often SPC investors.

When providing infrastructure and public services, the government (or public institution) normally places orders directly with suppliers in the form of public works projects, after which public institutions such as national railway or highway companies operate the infrastructure. However, in PPPs, capital procurement and operational risk are shared by both parties, and performance is often improved. Particularly in emerging countries, infrastructure demand exceeds public funding, and government agencies lack the necessary experience to operate the businesses. Thus, PPPs with their private specialty technology and knowhow are analyzed with high expectations. PPPs are a form of alliance between public and private sectors. Note that this is different from the subcontracting and outsourcing shown in Fig. 7.1. In the case of public works projects, the government decides the infrastructure specifications, and private companies place bids for the business, making these projects similar to outsourcing or subcontracting. In comparison, PPP agreements promote innovation within private companies in the process of infrastructure creation through business operation. Such a framework is created with the intention to increase public services' return on investment (ROI). This does not imply that governments completely allocate the provision of public services to private companies. The government must ultimately provide a stable, high-quality service to citizens, and monitor the activities of private companies, while being involved in the operation of the business as required. Alternatively, where continuing a business led by private companies has become difficult because of unforeseen changes in the economic environment at the time when the PPP alliance was created, government institutions can support the business itself through policy benefits and funding. Between public institutions that aim at increasing public welfare and for-profit private corporations, there are, to a certain extent, contradictions in policy in the operation of the business, but ultimately, creating a relationship of trust between public and private sectors to establish a win-win situation is critical. This feature has a lot in common with alliance management between private companies. 
There are general risks in the construction and operation of infrastructure projects, such as economic changes and disasters, as well as business-specific risks such as construction delays or a decline in the number of users. On directly operating the business by a country, these risks fall on the country itself; however, in case of a PPP, the risk is shared between public and private sectors. The value added of PPP businesses arises from risk-sharing optimization. Figure 7.3 summarizes the various risks associated with infrastructure projects that are to be assumed by government (or public institutions) or the main driver of the business-the SPC. The overall project is divided into the infrastructure creation stage (engineering, procurement, and construction, (EPC)) and service stage (operation and management, (O\&M)). In the EPC stage, the government assumes the risk of land acquisition and delays in administrative procedures. First, system design occurs before the EPC stages. This design is formulated by specialists and is based on the government's business goals in terms of the public service, its scope, and service levels. The risk of design deficiencies is, of course, borne by the government. On the other hand, capital procurement for EPC is done by the SPC, and finance risk should be borne by the private sector. As for procurement and construction, necessary work should be given to equipment manufacturers and construction companies. For example, construction risk, such as delays in construction, should be borne by the private sector (the SPC and subcontracted construction company).

Once the infrastructure is in place, projects enter the O\&M stage, with risks of administrative procedure delays, which push back the launch of services, and political risks that originate from regulatory and policy changes during the term of the PPP agreement. Therefore, these risks should be borne by the government. On the other hand, the SPC that operates the business should undertake the responsibility

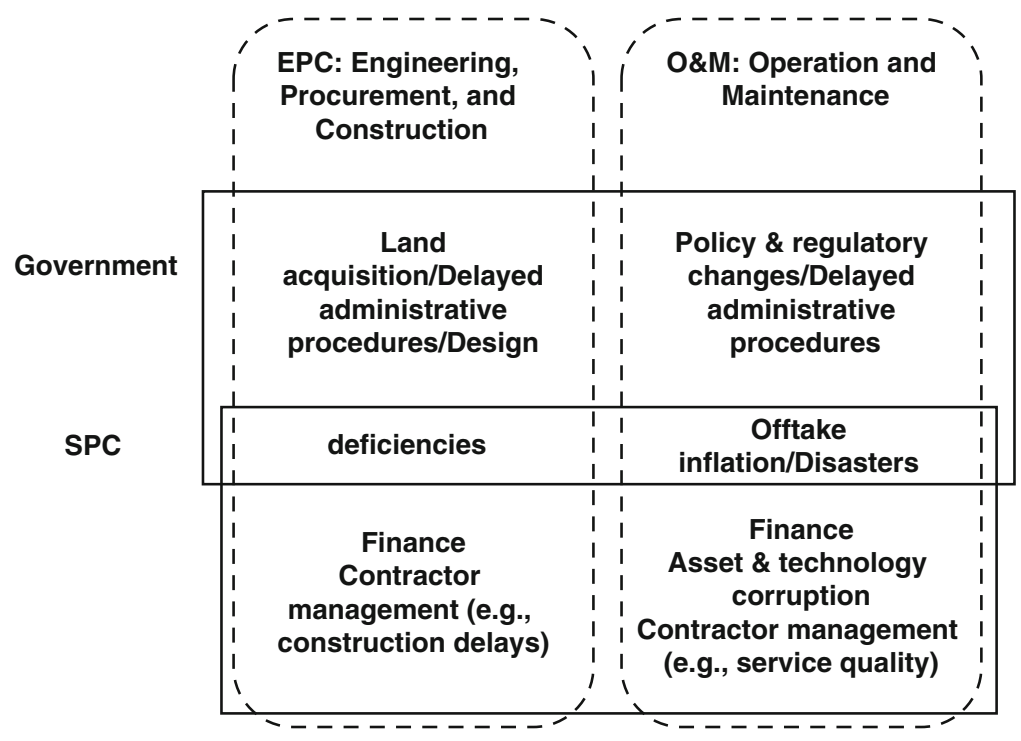

Fig. 7.3 Risk sharing between public and private entities 
of stably providing a certain level of service during the term of the PPP agreement. To do so, the management of the infrastructure service may be contracted to a specialty company, in which case the risks in that agreement should be borne by private companies. Asset and technology obsolescence and financial risk should be assumed by private companies in principle. In the O\&M stage, depending on the businesses, both public and private sectors must consider the optimal sharing of risk. For example, the risks of inflation or disasters cannot be controlled by either public or private entities. It is normal for both parties to clearly delineate how these risks are to be shared in the PPP agreement. Furthermore, using disaster insurance externalizes disaster-related risks, and the fees can be added to the operating costs of the business. Off-take risk (from users) is important during the O\&M stage. However, the risk size depends on the nature of the infrastructure. For example, governments or public institutions enter into long-term service acquisition agreements for wastewater treatment businesses because, generally, the amount of wastewater to be treated does not overly fluctuate, thus creating a marginal off-take risk. On the other hand, in a railway business, the number of passengers, as well as long-term changes in them, cannot be accurately forecasted. In addition, fares must typically be approved by the relevant government agency; therefore, it is likely that such fares will be offered at subsidized rates - typical for a public service. Accordingly, these kinds of services have a high off-take risk. The off-take risk in railway services can become too large, and it is typical for governments to undertake a certain amount of risk as part of the PPP agreement, with provisions for government subsidies on fares when the number of expected passengers drastically falls (so-called ridership clause).

Emerging countries do not often have a legal code governing PPPs, and government agencies lack such knowledge. This sometimes causes negotiations for agreements and business operation to go awry. There are also great political risks due to agreements being trashed by political instability or regime changes. These political risks must be accepted as part of conducting business for private companies overseas, and are likely to be the greatest risk factor in the infrastructure business within emerging countries. However, PPP businesses must not exclusively be perceived as businesses between governments and private companies; there is an analytical framework that accounts for the intent of service recipients, such as civic action in the partner nation (Kivleniece and Quelin 2012). This framework treats civic actions referred here as a force that confronts political risk with a bias toward the government's objective of maximizing public interests in politicians' election cycles. In democracies such as India, where one can relatively depend on the power of civic action, it is possible to minimize political risk by providing quality public services to local residents. Corporate social responsibility (CSR) activities are another effective means to this end.

That said, in emerging countries with little government experience in PPP businesses, one cannot depend on risk sharing, as shown in Fig. 7.3. Generally, in these cases, it is appropriate to have an agreement that offers a high degree of independence to private operators, which, to the extent possible, does not allow interference by the partner government through monitoring of the business. However, in such a case, the private company must bear a larger share of risk. Accordingly, the needs 
may be high for PPP businesses in emerging countries, but in reality, the risks are too high for private companies to independently undertake, and therefore not many companies enter the infrastructure businesses in these countries. Japanese companies, in particular, have a strong track record as equipment suppliers, such as water treatment membranes for water projects and train cars for railway systems, but have not participated as operators of these businesses. Infrastructure exports have been prioritized in the government policy and measures have been taken to strengthen the trade insurance system and utilize official development assistance (ODA). However, conducting risk analysis for projects or countries and painstakingly negotiating the required risk sharing with the partner government agencies is what is required the most. In doing so, companies must select businesses that are in high demand in specific countries to develop compelling proposals that have merit for these countries too. It will also be effective to partner with local companies or companies in countries, such as Singapore, that are working actively on expanding infrastructure businesses in India and China.

\subsection{Conclusion}

In this chapter, we discussed alliance strategy and management for global businesses. The creation of a local entity presents pros and cons to wholly owned subsidiaries and joint ventures. In summary, selection of the tradeoff is between reducing pre-market entry risk (joint ventures) and post-market entry risk (wholly owned subsidiaries). Reducing ex post facto risk through joint ventures requires a management appropriate to each phase in an alliance: alliance formulation, alliance structure design, and alliance execution. It is also effective for companies to create a knowledgebase of alliance experience and establish a specialized division that focuses on alliances to effectively move forward with new deals. Companies with a high level of alliance management capability can reduce the ex post facto risk of joint ventures, and thus opt to make business transformations through alliances with local companies.

In this chapter, we discussed the expansion of global businesses through alliances based on the creation of complementary relationships with local companies. Strategic international alliances can take on the forms of co-specialization (partnerships with complementary assets), co-option (selective partnerships with competitors) to pursue scale merit at a global level, and learning and internalization with the objective of strengthening internal capabilities through an alliance (Doz and Hamel 1998). Co-option is prominent in the electronics industry, which requires speedy business decision-making and scale merit. On the other hand, learning and internalization is appropriate to the automotive industry, where it is critical to increase productivity by adopting strength in production and other technologies that differ from one company to another. Japanese companies tend to exhibit the "not invented here" syndrome and lag behind in terms of creating international alliances. However, alliance strategy is an important component in a company's management strategy from a global perspective, and it is thus important for companies to deepen their understanding of various forms of alliances and proactively work on these alliances. 
We concluded this chapter by discussing government alliances in the form of infrastructure businesses through PPPs. They do not merely involve the subcontracting of operations by governments to private corporations, and must be understood as an alliance between public and private sectors to increase business values by sharing business risks and maximizing benefits to both parties that form the alliance. Governments in emerging countries possess limited ability to manage PPP businesses, thus private companies have no other option but to undertake excess risk. Despite the high risks, the incentives to pursue infrastructure business-related PPPs in emerging countries is strong, and such business opportunities abound. Japanese companies must therefore carefully analyze the underlying risks related to infrastructure projects and make business proposals on the basis of governments' needs in these countries, and patiently negotiate the sharing of appropriate risk levels. Companies may also find it effective to enter into alliances with local companies in negotiating projects with governments in host countries.

Open Access This chapter is distributed under the terms of the Creative Commons Attribution Noncommercial License, which permits any noncommercial use, distribution, and reproduction in any medium, provided the original author(s) and source are credited.

\section{References}

Anand, B., \& Khanna, T. (2000). Do firms learn to create value? The case of alliances. Strategic Management Journal, 21(3), 295-315.

Beamish, P. (1987). Joint ventures in LDCs: Partner selection and performance. Management International Review, 27(1), 23-27.

Doz, Y. L., \& Hamel, G. (1998). Alliance advantage: The art of creating value through partnering. Boston: Harvard Business School Press.

Hennart, J. (1988). A transaction cost theory of equity joint venture. Strategic Management Journal, 9(2), 141-158.

Kale, P., \& Singh, H. (2009). Managing strategic alliances: What do we know now and where do we go from here? Academy of Management Perspectives, 26(2), 45-62.

Khanna, T. \& Palpu K. G. (2010). Wining in emerging markets: A roadmap for strategy and execution. Boston: Harvard Business School Press.

Kivleniece, I., \& Quelin, B. V. (2012). Creating and capturing value in public-private ties: A private actor's perspective. Academy of Management Review, 27(2), 272-299.

Motohashi, K. (2011). Chapter 1. Shinkoukoku Shijou ni Muketa Gijutsu Keiei Management: Nihon Kigyou no Genjou to Kadai. In W. Toshiya (Ed.), Global Business Senryaku. Tokyo: Hakuto Shobo.

Ring, P., \& Van de Ven, A. (1994). Developmental processes of cooperative interorganizational relationships. Academy of Management Review, 19(1), 90-118. 